\title{
5. TEXTURAL CHARACTERISTICS OF OLIGOCENE SUBMARINE DEBRIS-FLOW DEPOSITS, SITES 792 AND $793^{1}$
}

\author{
Kelvin S. Rodolfo, ${ }^{2}$ A. Tevfik Arguden, ${ }^{2}$ and Renato U. Solidum ${ }^{2,3}$
}

\section{INTRODUCTION}

Subaerial debris flows, with water contents ranging from as little as $10 \mathrm{wt} \%$ up to no more than about $25 \mathrm{wt} \%$ (Pierson, 1986; Pierson and Costa, 1987), are non-Newtonian fluids that move as fairly coherent masses with yield strength (owing to bulk densities and viscosity that are much greater than those of clear water), which enables them to suspend and transport large clasts. Their flow behavior is thought to be predominantly laminar, although the relative importance of laminar and turbulent flow has not been established and is debatable. They leave deposits (debrites) that are characteristically poorly sorted with large clasts in their middle portions and commonly protruding from their tops. Although generally ungraded or normally graded in their upper portions, many have centimeter- to decimeter-thick inversely graded basal zones (Arguden and Rodolfo, 1990).

Submarine debris flows and debrites have also been recognized, but they are not as well known as subaerial flows. Their recognition is rendered difficult by several serious limitations. Not only can they not be observed while moving, but unambiguously submarine deposits are not very accessible. Thus, one of the few studies of subaqueous debrites (Kessler and Moorhouse, 1984) had to rely on cores of ancient deposits; this exacerbates the difficulty by presenting for analysis the two-dimensional surfaces of split cores, a limitation the present study shares. Most of what we know about the behavior of debris flows necessarily comes from studies of subaerial flows, and extrapolation of this information to the submarine environment doubtlessly introduces errors. Pickering et al. (1989, pp. 31-32) have stated that submarine flows "... probably have lower yield stress than subaerial flows as a result of entrainment of seawater and wet mud, lack of downward percolation into the substrate, and elevated pore pressures due to greater amounts of interstitial fluids . . .," and substantiate this claim by citing several workers who have shown that subaqueous debrites tend to contain smaller boulders, presumably because subaqueous debris flows have less strength.

In a study of Upper Jurassic debrites in drill cores, Kessler and Moorhouse (1984) have found that, compared with subaerial debrites, subaerial ones have ". . . Better ordered fabric, matrix support, and poor correlation between maximum clast size and flow thickness ..." Gloppen and Steel (1981), in a comparison of Devonian subaerial and subaqueous debrites, reported that the subaqueous debrites tend to be finer grained and have higher percentages of sand matrix and BTh/MPS ratios (5-6 vs. <3). Submarine debris flows must differ in one important aspect from subaerial ones, purely by virtue of their being overlain by water instead of air. It may be typical for them to

\footnotetext{
'Taylor, B., Fujioka, K., et al., 1992. Proc. ODP, Sci. Results, 126: College Station, TX (Ocean Drilling Program).

${ }^{2}$ Department of Geological Sciences, M/C 186, University of Illinois at Chicago, P.O. Box 4348, Chicago, IL 60680, U.S.A.

${ }^{3}$ Present address: Philippine Institute of Volcanology and Seismology, Hizon Building, Quezon Avenue, Quezon City, Philippines.
}

undergo an upward transition into a classic turbulent turbidity currents by admixture with the overlying water column. Finally, what we know regarding subaqueous debris flows has come mainly from nonvolcanic terrains, and even exclusively subaerial volcaniclastic (laharic) debris flows may differ significantly from nonvolcanic ones in ways that are only now becoming apparent (cf. Rodolfo, 1989; Arguden and Rodolfo, 1990; Rodolfo and Arguden, 1991).

Numerous subaqueous debrites (debris-flow deposits) were cored in the Oligocene successions of the Izu-Bonin forearc basin at Sites 792 and 793 during Ocean Drilling Program (ODP) Leg 126. These were described in detail on shipboard; however, because of time pressures during drilling, these initial descriptions were incomplete. Accordingly, we examined most of the debrites in more detail during a visit to the ODP core repository at Texas A\&M University in December 1989. Combined results of the shipboard and shore-based observations are presented in Table 1, which will serve as the primary bases for continuing analysis. The table also contains a single entry for a debrite at Site 787 .

\section{METHODS}

Table 1 was constructed by checking and refining the shipboard descriptions (Taylor, Fujioka, et al., 1990, pp. 671-753 and 787-879). Bed thicknesses in meters, listed in the BTh column of Table 1 debrites and intraclast breccias, are a key parameter. In some cases, to select the tops and bottoms of debrites, we augmented information from visual core descriptions and core photographs with data extracted from formation microscanner (FMS) records by Hiscott et al. (this volume). Wherever the information was available, we noted the nature of top and bottom contacts $(\mathrm{G}=$ gradational and $\mathrm{E}=$ erosional), and described the presence of grading at the top, middle, and base of each bed $(\mathrm{N}=$ normal, $\mathrm{I}=$ inverse, and $\mathrm{U}=$ ungraded $)$. Bed thickness was easily determined for a few beds with sharp tops and bottoms; however, an erosional top indicates that the original thickness of the debrite must have been reduced by an indeterminate amount between beds with sharp and gradational tops.

We feel that the submarine process that leaves true debrites may be rheologically indistinguishable from the process responsible for producing the coarse basal layers of some turbidites, but for diamictites that fine upward into sandstones, our bed thickness data are somewhat subjective. In such cases, our usual practice was to select the debrite top as the horizon where sediment of granule sizes and coarser are no longer abundant; these limits are also commonly marked by the appearance of laminations. We measured intermediate diameters of the coarsest clasts in each bed by hand, distinguishing between lithic, pumiceous, and oxidized volcaniclastic fragments. In two of the lithic debrites, sedimentary intraclasts were also present, and three intervals were sedimentary intraclastic breccias, without coarse lithic clasts, in sandstone matrices. To gain insight on their formation, we also measured and report the intraclast data separately. Table 1 presents, for each clast type, the sizes in millimeters of the largest clast in the bed (Max.) as well as the average of the ten largest clasts (Ave.). Using only the average values for each clast type, we have calculated ratios of bed thickness to maximum particle size (BTh/MPS). 


\begin{tabular}{|c|c|c|c|c|c|c|c|c|c|c|c|c|c|c|c|c|c|c|c|c|c|}
\hline \multirow[b]{4}{*}{ Core, section } & \multirow{4}{*}{$\begin{array}{l}\text { Top } \\
\text { (cm) }\end{array}$} & \multirow{4}{*}{$\begin{array}{c}\text { Bottom } \\
\text { (cm) }\end{array}$} & \multirow{4}{*}{$\begin{array}{l}\text { Depth } \\
\text { (mbsf) }\end{array}$} & \multirow[b]{4}{*}{ BTh } & \multicolumn{12}{|c|}{ Clast types } & \multirow{3}{*}{\multicolumn{2}{|c|}{ Contact }} & \multirow{3}{*}{\multicolumn{3}{|c|}{ Grading }} \\
\hline & & & & & & & & & & & & Igneou & & & & & & & & & \\
\hline & & & & & \multicolumn{3}{|c|}{ Sedimenary } & \multicolumn{3}{|c|}{ Lithic } & \multicolumn{3}{|c|}{ Pumice } & \multicolumn{3}{|c|}{ Oxidized } & & & & & \\
\hline & & & & & Max. & Ave. & BTh/MPS & Max. & Ave. & BTh/MPS & Max. & Ave. & BTh/MPS & Max. & Ave. & BThMPS & Top & Base & Top & Mid & Base \\
\hline $\begin{array}{r}126-787 \mathrm{~B}- \\
32 \mathrm{R}-1 \\
32 \mathrm{R}-2\end{array}$ & 0 & 51 & 291.30 & 2.00 & 300 & 98 & 20.4 & 12 & 7 & 270.3 & & & & & & & E & $\mathrm{N}$ & $\mathrm{N}$ & 1 & \\
\hline \multirow{9}{*}{$\begin{array}{r}126-792 E- \\
40 R-6 \\
41 R-1 \\
4 R-1 \\
42 R-5 \\
42 R-5 \\
42 R-6 \\
42 R-6 \\
43 R-3 \\
43 R-6 \\
44 R-1 \\
45 R-3 \\
47 R-3 \\
47 R-2 \\
47 R-2 \\
48 R-3 \\
49 R-1 \\
49 R-1 \\
4 R-2 \\
49 R-5 \\
49 R-6 \\
5 R-3 \\
5 R-3 \\
5 R-3 \\
6 R R-2\end{array}$} & $\begin{array}{r}22 \\
0\end{array}$ & 76 & $\begin{array}{l}519.62 \\
521.60\end{array}$ & $\begin{array}{l}0.54 \\
1.89\end{array}$ & $\begin{array}{l}45 \\
13\end{array}$ & & & $\begin{array}{l}21 \\
29\end{array}$ & $\begin{array}{l}13 \\
14\end{array}$ & $\begin{array}{r}41.5 \\
140.0\end{array}$ & & & & 23 & & & G & $\stackrel{\mathrm{E}}{\mathrm{E}}$ & N & U & i \\
\hline & 0 & 39 & 537.30 & 1.87 & 30 & & & 43 & 20 & 92.1 & & & & 14 & 6 & 311.7 & & E & & $\mathrm{N}$ & 1 \\
\hline & 105 & $\begin{array}{r}37 \\
105\end{array}$ & 539.75 & 4.90 & 80 & 41 & 121.0 & 36 & 18 & 272.2 & & & & & & & E & E & N & $\mathrm{N}$ & N \\
\hline & 110 & 130 & 549.20 & 2.40 & 50 & 26 & 90.9 & & & & & & & 10 & 8 & 300.0 & E & E & u & u & 1 \\
\hline & 30 & 65 & 563.30 & 18.25 & 90 & 55 & 331.8 & 41 & 24 & 760.4 & & & & & & & & E & & & 1 \\
\hline & 90 & 130 & 581.80 & 1.90 & & & & 43 & 32 & 59.4 & & & & & & & G & E & U & u & U \\
\hline & 122 & 64 & $\begin{array}{l}588.69 \\
599.02\end{array}$ & $\begin{array}{l}0.55 \\
0.65\end{array}$ & $\begin{array}{l}78 \\
62\end{array}$ & $\begin{array}{l}28 \\
30\end{array}$ & $\begin{array}{l}20.0 \\
21.7\end{array}$ & $\begin{array}{r}10 \\
6\end{array}$ & 3 & $\begin{array}{l}122.2 \\
216.7\end{array}$ & & & & & & & G & $\begin{array}{l}\mathrm{E} \\
\mathrm{E}\end{array}$ & $\stackrel{N}{N}$ & $N$ & N \\
\hline & 97 & 37 & 604.77 & 0.83 & 80 & 42 & 19.8 & 12 & 7 & 118.6 & & & & & & & G & E & 1 & $\mathrm{~N}$ & 1 \\
\hline & $\begin{array}{l}51.5 \\
83 \\
132\end{array}$ & $\begin{array}{r}58 \\
88 \\
142\end{array}$ & $\begin{array}{l}620.62 \\
620.93 \\
716.42\end{array}$ & $\begin{array}{l}0.06 \\
0.05 \\
0.10\end{array}$ & $\begin{array}{l}26 \\
12\end{array}$ & 10 & 6.0 & 6 & 3 & $\begin{array}{l}20.0 \\
16.7\end{array}$ & & & & 10 & 7 & 14.3 & $\begin{array}{l}E \\
G \\
G\end{array}$ & $\begin{array}{l}\mathrm{E} \\
\mathrm{E} \\
\mathrm{G}\end{array}$ & & & 1 \\
\hline \multirow{5}{*}{$\begin{array}{r}126-793 \mathrm{~B}- \\
20 R-5 \\
22 R-3 \\
27-5 \\
27 R-5 \\
27 R-5 \\
27 R-6 \\
28 R-2 \\
28 R-3 \\
28 R-6 \\
28 R-7 \\
280\end{array}$} & & & & & 111 & 30 & 25.7 & \multirow{3}{*}{17} & \multirow{3}{*}{10} & \multirow{3}{*}{59.4} & & & & & & & \multirow{3}{*}{$\begin{array}{l}\mathrm{G} \\
\mathrm{G} \\
\mathrm{E}\end{array}$} & & \multirow{3}{*}{$\stackrel{N}{N}$} & \multirow{3}{*}{$\underset{U}{U}$} & \multirow{3}{*}{${ }_{\mathrm{N}}^{\mathrm{N}}$} \\
\hline & 48 & $\begin{array}{l}73 \\
64\end{array}$ & $\begin{array}{l}790.78 \\
841.44\end{array}$ & $\begin{array}{l}0.25 \\
0.60\end{array}$ & 111 & 30 & 1200 & & & & 14 & ii) & 81.1 & & & & & E & & & \\
\hline & 127 & O4 & 842.04 & 0.38 & $\frac{28}{7}$ & 5 & 76.0 & & & & 9 & 6 & 69.1 & & & & & $\mathrm{E}$ & & & \\
\hline & 125 & 125 & 847.85 & 0.38 & & & & & & & & 10) & 9 & 42.2 & & & G & $\mathrm{E}$ & 1 & u & u \\
\hline & 110 & 105 & 853.70 & 1.40 & 21 & 13 & 112.0 & \multirow[b]{2}{*}{7} & & & & & & & & & G & E & U & u & u \\
\hline $\begin{array}{l}28 R-7 \\
28 R-1 \\
280.1\end{array}$ & $\begin{array}{r}100 \\
0\end{array}$ & 106 & $\begin{array}{l}855.10 \\
854.70\end{array}$ & $\begin{array}{l}0.06 \\
3.83\end{array}$ & 30 & 12 & 330.2 & & 6 & 10.9 & 15 & 1.3 & 288.0 & & & & E & E & U & U & ${ }_{i}^{N}$ \\
\hline $\begin{array}{l}28 \mathrm{R}-3 \\
30 \mathrm{R}-1\end{array}$ & 5 & 83 & 864.45 & 4.31 & 18 & 13 & 344.8 & 25 & 16 & 278.1 & & & & & & & G & E & u & u & 1 \\
\hline $\begin{array}{l}30 R-3 \\
32 R-2 \\
300\end{array}$ & 0 & 136 & 885.20 & 5.40 & & & & 27 & 14 & 397.1 & & & & 7 & & & & E & N & & \\
\hline $\begin{array}{l}32 R-C C \\
38 R-3 \\
39 R-1\end{array}$ & 37 & $\begin{array}{l}40 \\
15\end{array}$ & 994.97 & 6.48 & 330 & 138 & 47.0 & & & & 25 & 11 & $57 \times .6$ & 7 & 3 & 2160.0 & G & E & N & & 1 \\
\hline $54 R-4$ & $\begin{array}{r}107 \\
0\end{array}$ & & $\begin{array}{l}1004.97 \\
1108.40\end{array}$ & $\begin{array}{l}1.02 \\
9.15\end{array}$ & & & & 57 & $16^{2}$ & $\begin{array}{l}680.0 \\
568.3\end{array}$ & & & & 16 & 5 & 1830.0 & G & $\underset{G}{E}$ & $\stackrel{\mathrm{U}}{\mathrm{N}}$ & $\stackrel{N}{N}$ & i \\
\hline $\begin{array}{l}56 R-2 \\
57 R-2 \\
57-4\end{array}$ & 135 & 105 & 1127.55 & 3.05 & 25 & & & & & & & & & & & & G & & $\mathrm{N}$ & & \\
\hline $\begin{array}{l}57.4 \\
60 R-6 \\
60 R-7\end{array}$ & 110 & 75 & 1161.80 & 1.15 & 52 & 16 & 71.9 & 7 & 4 & 287.5 & & & & & & & G & E & $\mathrm{N}$ & $\mathrm{N}$ & $\mathrm{N}$ \\
\hline $\begin{array}{l}61 \mathrm{R}-1 \\
64 \mathrm{R}-6 \\
6 \mathrm{R}-3\end{array}$ & $\begin{array}{l}48 \\
60\end{array}$ & $\begin{array}{l}94 \\
60\end{array}$ & $\begin{array}{l}1163.38 \\
1200.00\end{array}$ & $\begin{array}{l}0.46 \\
5.10\end{array}$ & 55 & 13 & 392.3 & 15 & $\begin{array}{l}10 \\
9\end{array}$ & $\begin{array}{r}46.0 \\
554.3\end{array}$ & & & & $\underset{8}{11}$ & $\begin{array}{l}4 \\
5\end{array}$ & $\begin{array}{r}115.0 \\
1133.3\end{array}$ & $\underset{G}{E}$ & $\underset{E}{E}$ & $\stackrel{U}{N}$ & $\mathrm{u}$ & i \\
\hline $\begin{array}{l}69 R-3 \\
67 R-1 \\
6 R-4\end{array}$ & 55 & 72 & 1221.35 & 4.67 & & & & 7 & 4 & 1167.5 & & & & & & & G & $\mathrm{E}$ & N & $\mathrm{N}$ & 1 \\
\hline $\begin{array}{l}6 / R-4 \\
72 R-5 \\
73 R-1\end{array}$ & 90 & $\begin{array}{l}72 \\
32\end{array}$ & 1275.60 & 3.12 & 20 & 5 & 624.0 & 11 & 10 & 312.0 & & & & 19 & 10 & 328.4 & E & $\mathrm{E}$ & $\mathrm{N}$ & & 1 \\
\hline $\begin{array}{l}78-1 \\
74 R-4 \\
75 R-3\end{array}$ & 60 & 21 & 1293.10 & 7.81 & 210 & 13 & 624.8 & 22 & 14 & 557.9 & & & & 26 & 13 & 610.2 & & E & $\mathrm{N}$ & $\mathrm{N}$ & 1 \\
\hline $\begin{array}{l}78 \mathrm{R}-2.2 \\
78 \mathrm{R}-3\end{array}$ & 2 & 113 & 1328.22 & 2.61 & 45 & & & 16 & 10 & 261.0 & & & & 8 & & & G & $\mathrm{E}$ & U & u & u \\
\hline $\begin{array}{l}79 R-1 \\
80 R-4\end{array}$ & 0 & 27 & 1336.40 & 14.37 & 33 & 13 & 1088.6 & & & & 40 & 8 & 1916.0 & & & & G & E & u & $\mathrm{u}$ & 1 \\
\hline
\end{tabular}




\section{SOME PRELIMINARY RESULTS}

All BTh/MPS ratios are very high, averaging 293 for the lithic debrites and 223 for the sedimentary intraclasts. The values reported by Kessler and Moorhouse (1984) for much more proximal submarine fan deposits are 2 orders of magnitude lower, mainly because the clasts in the Izu-Bonin debrites are much smaller, probably because of their distal position. Sites 792 and 793 are respectively 40 and $80 \mathrm{~km}$ away from the modern volcanic front. The disparity may also be enhanced by greater fluidity of the distal flows.

Our results corroborate the findings of Gloppen and Steel (1981) and Kessler and Moorhouse (1984) that, compared with subaerial debrites, subaqueous debrites have poorer, although statistically significant, correlations between maximum clast size and bed thickness. For all lithic debrites $(N=25), r^{2}=0.26$. We find no such correlation for oxidized and pumice clasts, probably because of their variable densities.

All the data for sedimentary intraclasts taken as a group show no BTh/MPS correlation. However, there is a correlation if only ungraded beds with or without basal inverse grading are considered $\left(n=9, r^{2}=0.55\right)$. Sedimentary rip-up clasts are much larger, for an interval of given thickness, than the lithic clasts in a debrite, which explains why their BTh/MPS ratios are lower. This strongly suggests that the mechanics of formation and flow of intraclastic breccias are different from those of coarse deposits in which the larger clasts are predominantly lithic. Those that occur in sandstone intervals that lack lithic clasts of granule size and larger may have been produced by erosion of the substrate by turbidity currents. Postma et al. (1988) have suggested that large intraclasts can be suspended fairly high within a turbidity current by turbulence, they then are transported along the boundary between a basal, highly concentrated inertia-flow layer and the overlying, faster turbulent-flow layer.

\section{REFERENCES}

Arguden, A. T., and Rodolfo, K. S., 1990. Sedimentologic and dynamic differences between hot and cold laharic debris flows of Mayon Volcano, Philippines. Geol. Soc. Am. Bull., 102:865-876.
Gloppen, T. G., and Steel, R. G., 1981. The deposits, internal structure and geometry of six alluvial fan-fan delta bodies (Devonian, Norway) - a study in the significance of bedding sequences in conglomerates. In Ethridge, $\mathrm{F}$. M. and Flores, R. M. (Eds.), Recent and Ancient Non-marine Depositional Environments: Models for Exploration. Spec. Publ., Soc. Econ. Paleontol. Mineral., 31:46-69.

Kessler, L. G., II, and Moorhouse, K., 1984, Depositional processes and fluid mechanics of Upper Jurassic conglomerate accumulations, British North Sea. In Kessler, E. H., and Steel, R. J. (Eds.), Sedimentology of Gravels and Conglomerates. Mem., Can. Soc. Pet. Geol., 10:383-397.

Pickering, K. T., Hiscott, R. N., and Hein, F. J., 1989. Deep Marine Environments: Clastic Sedimentation and Tectonics: London (Unwin Hyman).

Pierson, T. C., 1986. Flow behavior of channelized debris flows, Mount St. Helens, Washington. In Abrahams, A. D.(Ed.), Hillside Processes: Boston (Allen \& Unwin), 269-296.

Pierson, T. C., and Costa, J. E., 1987. A rheologic classification of subaerial sediment-water flows. Geol. Soc. Am., Rev. Eng. Geol., 7:1-12.

Postma, G., Nemec, W., and Kleinspehn, K. L., 1988. Large floating clasts in turbidites: a mechanism for their emplacement. Sediment. Geol., 58:47-61.

Rodolfo, K. S., 1989. Origin and early evolution of lahar channel at Mabinit, Mayon Volcano, Philippines. Geol. Soc. Am. Bull., 101:414-426.

Rodolfo, K. S., and Arguden, A. T., 1991. Rain-lahar generation and sedimentdelivery systems at Mayon Volcano, Philippines. In Fisher, R. J. and Smith, G. A. (Eds.), Sedimentation in Volcanic Settings. Spec. Publ.-Soc. Econ. Paleontol. Mineral., 45:71-87.

Taylor, B., Fujioka, K., et al., 1990. Proc. ODP, Init. Repts., 126: College Station, TX (Ocean Drilling Program).

Date of initial receipt: 2 January 1991

Date of acceptance: 15 October 1991

Ms 126B-119 